\title{
台灣工業機器人協會活動
}

\section{6 年活動日程}

- 第二屆第一次會員大會暨第二屆第一次理監事會議

2016 年 1 月 10 日

- 2016 年(第 11 屆)工業機器人競賽

2016 年 1 月 10 日

- 2016 年工業機器人雜誌一第五期

2016 年 1 月出版

\section{5 年活動日程}

- 浙江省温州市科技局交流

2015 年 11 月 20 日

- 参加浙江省機器換人博覽會

2015 年 10 月 16 日

- 台灣工業機器人協會温州辦事處揭牌 2015 年 10 月 14 日

- 江蘇省常熟市招商局交流

2015 年 9 月 21 日

- 溫州・台灣工業機器人 技術交流會

2015 年 7 月 8 日

- 麗台工業機器人產業合作洽談會

2015 年 7 月 6 日

- Maker Faire Taipei 工業機器人競賽

2015 年 5 月 30 日

- 溫州市交流

2015 年 5 月 22 日

- 兩岸機器人產業：創新服務培育機器人產業紀實 2015 年 3 月 10 日

- 麗水市機器人產業聯盟：兩岸機器人產業友好合作備忘錄 